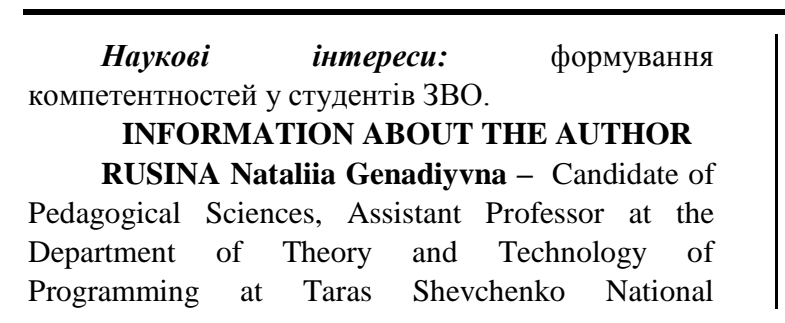

UDC 378.147

DOI:10.36550/2415-7988-2019-1-185-161-164
University of Kyiv.

Circle of research interests: formation of competencies in students of Higher education institutions.

Стаття надійшла до редакиї 28.10.2019 р.

\author{
SARNOVSKA Nataliia Ivanivna - \\ Lecturer, Foreign Languages Department \\ Kyiv National University of Culture and Arts \\ ORCID: https://orcid.org/0000-0001-7278-5183 \\ e-mail: nat_sarnovskaya@ukr.net \\ ANTONIVSKA Maryna Oleksandrivna - \\ Lecturer, Foreign Languages Department \\ Kyiv National University of Culture and Arts \\ ORCID: https://orcid.org/0000-0002-4451-3735 \\ e-mail: antonivska_maryna@ukr.net
}

\title{
THE DUAL SYSTEM AS ONE OF THE FEATURES OF SOCIO-CULTURAL SPHERE SPECIALISTS TEACHING AT THE MODERN STAGE OF EDUCATION
}

Formulation and justification of the problem topicality. The relevance of the study is due to the fact that the problem of improving the quality of education is becoming one of the most persistent problems not only for the education system, but also for the state as a whole. It is necessary to improve the quality of education at all stages of training specialists, at all levels of education and with the participation of all interested parties in the training process. The educational system is expected to provide professional readiness and the ability of teachers to this innovative activity. Domestic educational practice, despite the emergence in many educational organizations of new teaching techniques and methods, the active development of new forms, technologies, teaching aids and other pedagogical innovations, retains inertia and professional rigidity. The features and advantages of the dual education system in the training of specialists of the social and cultural sphere has not been sufficiently studied, despite the large number of micro-materials on this issue.

Analysis of previous studies and publications. The issues of improving the system of institutions of higher education were discussed and debated in both domestic and foreign research of A. M. Novikov, H. A. Borovskyi, V. A. Slastenin, A. P. Triapytsyn, V. Altunin, etc. In the field of higher education institutions the research of B. L. Agranovych, V. F. Vzyatyshev, L. S. Hore, V. M. Zhurakovskyi, and others reveal modern approaches to training, design of content and learning technologies. Development of integration tendencies in the system of education modelling is considered in the following works: H. G. Kadyrova, A. P. Andrieieva, P. F. Anisimov, Would. S. Hersonska, G. S. Ibragimov, A. M. Novikova, G. V. Osipov and I. P. Smirnov, E. V. Tkachenko, G. F. Filippov and others.

This suggests that there is an active search for new educational methods, allowing reorienting higher professional education to the satisfaction of the most important social and economic needs of students and the real industrial sector. At the same time, there is an optimal use in the educational activities of numerous innovative theoretical, methodological development, accumulated in vocational pedagogy over the past decade.

Based on the analysis of scientific pedagogical literature on the experience of the dual vocational training system in Germany, where it was born of dual system of education (G. A. Fedotova, V. A. Deshevym, E. A. Korchagina, A. N. Kirilovskyi, etc.), it can be concluded that the main system-forming factor of the German dual forms of vocational education were defined by the Institute of social partnership with a clear definition of the interests and responsibilities as an educational institution and the industrial employer. In search of the most effective ways of modernizing the national education, many scientists turn to the experience of foreign countries, in particular Germany. The most popular promoters of the ideas of German 
professional training of working personnel are N. Vorobiov, B. Wolfson, A. Piskunov, D. Toropov, H. Fedotov. In the study on the history of the German system development of vocational education, D. Toropov points out that the increasing pace of technological revolution, and in this regard, the emergence of new requirements in the labor market for its participants, have a strong influence on the system of vocational education in any industrialized country [8]. The dual training, as the practice of the European education system shows, is a product of interaction between educational organizations and employers on successful professional and social adaptation of the future specialist. The learner already in the early stages of the study process is included in the production process as an employee of the enterprise. In the famous work, «The Study of the Nature and Causes of the Wealth of Nations»» (1776), Adam Smith emphasized that the systems of apprenticeship and mentoring in dual training should be considered as traditional methods of vocational training in the workplace, since, while working alongside the master, young workers learned the basics profession [7]. The dual training model involves the involvement of enterprises in the training process, which incurs substantial costs associated with employee training, as they are well aware that the costs of quality vocational education are a reliable contribution of capital. In doing so, they become interested not only in the learning outcomes but also in the content of the training and its organization [4]. The dual system of education involves the combination of training with periods of production activity. The future specialist studies in two organizations, where, by definition, fans of catchy phrases, they have a cake and eat it, mastering both theory and practice. On the one hand, they are educated in an educational organization (it gives theoretical knowledge), and on the other - in a training enterprise, where the competencies necessary for the production are developed. Both organizations are partners in relation to each other. It is very important that young professionals who combine training with productive activities remain employed by the training enterprise.

The aim of the article is to highlight the peculiarities and advantages of the dual training system of specialists in the socio-cultural sphere in the context of training modernization in modern universities of arts and culture.

Representatives of business and international investors have been talking about the fact that Ukrainian higher education institutions and vocational schools graduate specialists who are generally not suitable for modern employers. The graduates cannot find work. The problem is not one year old, but only now Ukraine is at least a step away, but is close to changes. On 19 September 2018, the government approved the Concept of dual education. The seven-page document was discussed for two and a half years. After all, Ukraine has not invented anything new. The dual education exists in more than 50 countries of the world, and what the document offers is not much different from, say, German experience.

Experts are concerned about the date: 2023 is designated as the latest year when the Concept should be implemented. During this time, the relations of the world labor market and education will advance, and again we will be one step behind. However, according to the concept, we must come to the following scheme for the period of five years: university students and vocational schools will spend half their time at their desks, half at work. During training, they will have a mentor at the enterprise, a salary, and after graduation they will almost get a guaranteed job.

The results of such training will be evaluated by both the employer and the educational institution. The employer will participate in the selection of students who will work with him and will simultaneously study at the university. He must invest in the material and technical base so that the student gains a truly modern practical experience. A tripartite agreement will be concluded between the student, the employer and the educational institution, which will indicate the rights and obligations of each. But to launch the system, universities must modernize the curriculum, enterprises - the production base.

The main material of the study. The dual training system is a historically established form of professional education. It deeply entered the political, economic, religious and technological history of Europe. Today this training system is successfully used in Germany, Austria, Denmark, the Netherlands, Switzerland. The competitiveness of any country on the world market and the quality of life of its population depends directly on the level of professional training. One of the world's leading leaders in the field of skilled training today is the European Union, which owes this dual system to vocational education and training. The work on the introduction of dual education continues in Ukraine. In particular, a plan for the implementation of the Dual Education Specialist Training Concept was developed and approved by the Government. The relevant decree No. 214-r was adopted at a government meeting on April 3, 2019 [5].

In the near future, the Ministry of Education and Science specialists with stakeholders will create a Regulation on the dual 
form of obtaining professional, and further professional higher and higher education. By the end of 2019, a standard contract will also have to be approved by the employer, the institution's administration and the student

In parallel with the preparation of the regulatory framework, the development of new educational programs, curricula and criteria by which students and students will be evaluated will continue. In order to track the effectiveness of such education, the plan separately included monitoring of employment in the specialty of graduates who were trained in this form.

The implementation of pilot projects in higher and vocational higher education institutions is an important step, which is planned for the end of this year. The Ministry of Education and Science reminded that dual education is being introduced to ensure that students of vocational education institutions and university students have more opportunities to practice their professions in the course of training in institutions. It stipulates that up to $70 \%$ of the student's practical training will take place in real-world production, whereas up to $30 \%$ will be devoted to theoretical studies.

The education system in the field of culture and arts in our country has no analogues in the global educational space. It evolved over several centuries and, as they say, has passed the test of time, bringing up a galaxy of outstanding figures of art and culture with world names. But the rapid development processes taking place in almost all spheres of life in modern society dictate to us the need to modernize the existing education system in the country, including education in the field of art. Studying the experience of educational systems of advanced states allows a more critical approach to the problems of education and upbringing in his own country, gives an understanding of the need for changes in the field of professional education, favors pedagogical innovation. According to many scientists and practitioners, the state of students 'practical training, which has been observed in recent years, completely does not meet the requirements of today's employers, and this is due precisely to a decrease in attention to students' practical training. An important component of the preparation of a future competitive specialist is his competence, including intercultural competence. A person who is interculturally competent is someone who grasps and understands the specific concepts of perception, thinking, feeling and acting when working together with people from cultures that are foreign to him or her. Early experiences are included and extended as far as possible without prejudices while at the same time an attitude of openness and learning is necessary during the intercultural contact. [9, p. 86].
In the framework of the implementation of the model dual education system of vocational education of specialists in social and cultural sphere should take into account the specifics of their training, which implies a high degree of individualization of the learning process (high proportion of individual lessons) and a significant proportion of practical training. In addition, the «production» database, depending on the areas of training, implemented an educational institution of higher education, can reach theatres, museums, Philharmonic hall, libraries, recording studios, palaces and houses of culture, most of which are budget institutions whose expenditure is strictly regulated [2, p. 26].

The peculiarity of training personnel for the sphere of culture and the arts lies in the fact that it is carried out in three stages: prevocational education, secondary vocational and higher professional education - a three-stage system of training professional personnel, which includes a children's art school - college university. The general principles for training specialists in this field are:

- implementation of a practice-oriented modular training system; practical orientation of certification and final qualification works;

- high level of individualization of instruction;

- involvement of specialized specialists from cultural and art organizations in teaching and in taking state exams;

- the creation of professional creative teams based on educational institutions;

- conclusion of contracts with specialized organizations of culture and art for practice[3, $\mathrm{p}$. 23].

These principles and methods are being implemented at the Kiev National University of Culture and Arts.

Dual education can only eliminate the shortcomings of the educational process, because the development of training plans occurs only after a potential employer forms a complete list of competencies that a future specialist should possess. That is why, after such training, there is actually no time for an employee to adapt to the workplace, and his or her competences meet the requirements of the employer. In the case of a proper analysis of labor market needs, training should take place only in those specialties that will be required after 2 or 3 years, which first eliminates such problems of this market as the excess of some specialists and the shortage of others.

Conclusions and prospects for further researchers of directions. Achieving optimally high learning outcomes for highly qualified personnel in the cultural and arts sectors is unthinkable without creating a modern education model. In the conditions of deepening of the 
crisis of higher education in Ukraine, catastrophic state of preparation of specialists, unsatisfactory level of professional competence of the majority of graduates, corporatization of higher education is a real and perspective way out of the crisis. One form of corporatization is dual education.

\section{СПИСОК ДЖЕРЕЛ}

1. Дуальна освіта [Електронний ресурс] // Міністерство освіти і науки України : [офіц. портал]. - Текст. дані. - Київ, 2017.

2. Игнатова И. Б., Гричаникова И. А. Дуальное обучение как основа модернизации подготовки кадров в современном вузе искусств и культуры / И. Б. Игнатова, И. А., И. А. Гричанникова // Образование и общество, 2014. №4. - C. 25-30.

3. Игнатова И. Б., Покровская Е. А. Теоретические основы организации дуального обучения / Игнатова И. Б., Покровская Е. А. // Теория и история культуры, № 3 (62), 2016.

4. Опыт дуального обучения в Германии, Казахстане, России // «Агрегатор новостей образования». Информационно-аналитический журнал, 2018.

5. Про затвердження плану заходів 3 реалізації Концепції підготовки фахівців за дуальною формою здобуття освіти. Розпорядження // План від 03.04.2019№214

6. Розпочинається імплементація системи дуальної професійної освіти в Україні // Німецькоукраїнський агрополітичний діалог : [офіц. сайт проекту]. - Текст. дані. - Київ, 2017.

7. Смит А. Исследование о природе и причинах богатства народов А. Смит Серия: Антология экономической мысли. Дуальная модель обучения как основа механизма взаимодействия образовательных учреждений и предприятий // Заочные электронные конференции. - М. : Эксмо, 2007. - 960 с.

8. Торопов Д. А. История развития немецкой системы профессионального образования: Учебное пособие / Д. А. Торопов. // Российская Академия образования. - ИСПО РАО. М., 2002. Институт среднего профессионального образования.

9. Hesser Helmut Schmidt Implementation of a dual system of higher education within foreign universities and enterprises, 2017

10. Gregory Rayter Introduction of Dual Education in Ukrainian Higher Educational Establishments and Approaches to Estimation of its Economic Benefits, Business Ethics and Leadership, Volume 1, Issue 4, 2017.93

\section{REFERENCES}

1. Dualna osvita. (2017). [Dual education. [Ministry of Education and Science of Ukraine]. Kyiv.

2. Ihnatova, I. B., Hrychanykova, I. A. (2014). Dualnoye obrazovaniye kak osnova modernizatsii podgotovki kadrov v sovremennom vuze iskusstv I kultury. [Dual education as the basis for the modernization of training in a modern university of art and culture]. Moskow.

3. Ihnatov,a I. B., Pokrovskaya, Ye. A. (2016).
Teoreticheskiye osnovy organizatsyi dualnogo obucheniya. [Theoretical Foundations of the Organization of Dual Learning]. Moskow.

4. Opyt dualnogo obuchyeniya $v$ Germanii, Kazahstane, Rossii. (2018). [The experience of dual training in Germany, Kazakhstan, Russia] [Agregator novostey obrazovaniya]. Moskow.

5. Pro zatverdzhennia planu zahodiv z realizatsii Kontseptsii fahivtsiv za dualnoiu formoiu zdobuttya osvity. Rozporiadzhennia. Plan vid 03.04.2019№214 . [On approval of the plan of measures for the implementation of the Concept of training specialists in the dual form of education]. Kyiv.

6. Rozpochynaietsia implementatsiia dualnoii systemy osvity $v$ Ukraiyni. Nimetsko-ukraiynskyi agrarno-politychnyi dialog (2017). [Implementation of the dual vocational education system in Ukraine begins. German-Ukrainian Agrarian Policy Dialogue]. Kyiv.

7. Smith, A. (2007). Research on the nature and causes of the peoples wealth. Series: Anthology of economic thought. The dual learning model as the basis of the mechanism of interaction between educational institutions and enterprises. Moskow.

8. Toropov, D. A. (2002). Istoriya pazvitiya nemetskoy sistemy professionalnogo obrazovaniya. [The history of the development of the German vocational education system]. Moskow.

9. Hesser Helmut Schmidt

Implementation of a dual system of higher education within foreign universities and enterprises.

10. Gregory Rayter. (2017). Introduction of Dual Education in Ukrainian Higher Educational Establishments and Approaches to Estimation of its Economic Benefits, Business Ethics and Leadership.

\section{ВІДОМОСТІ ПРО АВТОРІВ}

САРНОВСЬКА Наталія Іванівна викладач кафедри іноземної філології Київського національного університету культури і мистецтв.

Наукові інтереси: сучасні освітні технології, викладання іноземних мов у закладах вищої освіти, міжкультурна комунікація.

АНТОНІВСЬКА Марина Олександрівна викладач кафедри іноземної філології Київського національного університету культури і мистецтв.

Наукові інтереси: методика викладання англійської мови у ЗВО, новітні парадигми, інтеркультурна комунікація, перекладознавчий аспект.

\section{INFORMATION ABOUT THE AUTHOR}

SARNOVSKA Nataliia Ivanivna - Lecturer of Foreign Philology Department, Kyiv National University of Culture and Arts.

Circle of scientific interests: modern educational technologies, teaching foreign languages in higher educational institutions, intercultural communication.

ANTONIVSKA Maryna Oleksandrivna Lecturer of Foreign Philology Department, Kyiv National University of Culture and Arts.

Circle of scientific interests: modern educational technologies, teaching foreign languages in higher educational institutions, intercultural communication.

Стаття надійшла до редакиії 15.11.2019 p. 